\title{
Non-Intubated Bilateral Single Port Endoscopic Thoracic Sympathectomy
}

\author{
Ekin Ezgi Cesur, ${ }^{1}$ Kadir Burak Özer, ${ }^{1}$ Attila Özdemir, ${ }^{1}$ Fatma Tuğba Özlü, \\ Fatih Doğu Geyik, ${ }^{2}$ Recep Demirhan'
}

\begin{abstract}
'Department of Thoracic Surgery, Kartal Dr. Lütfi Kırdar Training and Research Hospital, İstanbul, Turkey

${ }^{2}$ Department of Anaesthesiology and Reanimation, Kartal Dr. Lütfi Kırdar Training and Research Hospital, İstanbul, Turkey

Submitted: 11.05.2018 Accepted: 15.05.2018

Correspondence: Ekin Ezgi Cesur, Sağlık Bilimleri Üniversitesi Kartal Dr. Lütfi Kırdar Eğitim ve Araştırma Hastanesi Göğüs Cerrahisi Kliniği, İstanbul, Turkey

E-mail: ezgicesur@gmail.com
\end{abstract}

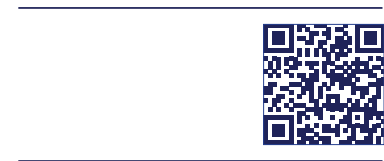

Keywords: Endoscopic thoracic sympathectomy; non-intubated video-assisted thoracoscopic surgery; primary hyperhidrosis; single-port video-assisted thoracoscopic surgery.

\begin{abstract}
Objective: Primary focal hyperhidrosis is excessive sweating required for body thermoregulation. The most commonly affected sites are the palms and axillae. It is a benign disease, but one which has physical, physiological, and social effects, especially for adults. The best treatment is a thoracic sympathectomy, which may be performed using different approaches. Thoracoscopy is generally performed with a $5-\mathrm{mm}$ thoracoscope and double lumen intubation. The aim of this study was to report experience with this technique using laryngeal mask ventilation, which is less invasive and shortens the operative time.
\end{abstract}

Methods: In all, 35 patients with palmar or axillar hyperhidrosis underwent a nonintubated endoscopic thoracic sympathectomy between January 2016 and August 2017. All of the patients were placed in a semi-Fowler position after the application of the laryngeal mask.

Results: The operative time, the expansion of the lung as seen on a postoperative chest $\mathrm{X}$-ray, and the postoperative pain score were recorded. The operative time was calculated from the first incision until the closure of the skin suture. The median length of the operation was $2 I \pm 3$ minutes. There were no complications seen in the first postoperative 24 hours and all of the patients were discharged after I day of hospitalization.

Conclusion: A nonintubated thoracoscopic sympathectomy procedure is a less invasive method that uses laryngeal mask, and which also reduces the operative time. As a result of bilateral ventilation, this procedure is highly effective at avoiding postoperative pneumothorax.

\section{INTRODUCTION}

Regional sweating is a condition that has a physical and psychological effect, and applications for surgical correction are increasing. Patients complain of excessive and chronic sweating, independent of their body temperature or the season on the face, hands, soles of the feet, or the axillary region. They frequently experience limitations in their social life and are treated psychologically, yet continue to seek other medical treatment.

Regional hyperhidrosis, on average, occurs in between $1 \%$ and $3 \%$ of the population, and in both sexes. The typical age at patient presentation varies from 16 to 35 years, but the 20s are most common. ${ }^{[l]}$ The condition develops as a result of localized autonomic sympathetic nervous system hyperactivity and is often triggered by psychological factors, such as stress and anxiety, which can create a vicious circle for the patient, exacerbating the problems originally created by the sweating. It is categorized as craniofacial hyperhidrosis (face and scalp), palmar hyperhidrosis (hands), axillary hyperhidrosis (armpits), inguinal hyperhidrosis (pubic area and legs), and plantar hyperhidrosis (feet). ${ }^{[2]}$

The symptoms typically begin in childhood but increase with puberty and hormonal changes. Increased anxiety and stress add to the psychological status, and may have an increasing effect on social life. The area where the sweating occurs, especially the hands, is cold, constantly wet, and 
red. The condition is usually symmetrical and the patient has no underlying internal problem or illness.

The sweat glands are grouped into eccrine and apocrine glands. The eccrine glands constitute three-fourths of the sweat glands in the body and produce colorless, odorless secretions. They are not connected to hair follicles. The apocrine glands are hormone-regulated sweat glands located in the urogenital and axillary regions that produce odorous secretions. Studies have found no difference in the number or histopathological structure of sweat glands. The sympathetic ganglion runs longitudinally on both sides of the vertebral column. There are 10 to 12 thoracic ganglia. The hypothalamus is activated by stress, hot air, increased physical activity, and sweat production from sweat glands is increased by sympathetic stimulation.

Palmar hyperhidrosis is a type of regional sweating that affects the social lives of patients, and therefore it is the most frequent cause of application for treatment. The diagnostic criteria specify that localized sweating should persist for at least 6 months and have worsened without any underlying cause. In addition, it should include at least 2 of the following criteria: ${ }^{[3]}$

I. Bilateral and symmetrical sweating,

2. Occurs at least once a week,

3. Leads to a restriction of daily activities,

4. Age at onset $<25$ years,

5. Presence of a family history,

\section{Lack of sweating during sleep}

The decision to perform a sympathectomy is made after excluding other underlying pathological conditions, such as malignancy or endocrine, drug-related, neoplastic, and neurological causes. Endoscopic thoracic sympathectomy operations may be performed using different techniques; however they are most frequently bilateral. It has been reported that in most centers, patients who underwent double lumen intubation followed by a 2-port incision also required a thoracic drain. In our clinic, a bilateral thoracic sympathectomy is performed with a laryngeal mask through a single-port incision. Due to the postoperative disadvantages of single-lung ventilation and the inability to optimally perform double-lumen intubation at every center, as well as the prolongation of operation time, it was the objective of this study to share the perioperative and postoperative results of cases treated with non-intubated endoscopic sympathectomy.

\section{MATERIAL AND METHODS}

A total of 35 patients who underwent bilateral endoscopic thoracic sympathectomy with a non-intubated, single-port incision between January 2016 and January 2017 were in-
Table I. Localization

\begin{tabular}{lcc}
\hline & $\mathbf{n}$ & $\%$ \\
\hline Isolated palmar hyperhidrosis & 18 & 51.4 \\
Palmoplantar hyperhidrosis & 8 & 22.8 \\
Craniofacial hyperhidrosis & 4 & 11.4 \\
Palmar and axillary hyperhidrosis & 3 & 8.5 \\
Raynaud phenomenon & 2 & 5.7 \\
\hline
\end{tabular}

cluded. There was palmar hyperhidrosis in 18 cases, palmar and plantar hyperhidrosis in 8 cases, craniofacial hyperhidrosis in 4, palmar and axillary hyperhidrosis in 3 , and Raynaud phenomenon in 2 cases (Table I).

Before the operation, all of the patients were informed of the details of the procedure and their written and verbal consent was obtained. The laryngeal mask was applied by the anesthesia team before the surgical procedure. After the patient was placed in a semi-Fowler position, the thoracic cavity was entered through a 5 -mm single-port incision made at the middle right axillary line at the level of the third intercostal artery from the end point of the hair follicles. The anesthesiologist was asked to interrupt the

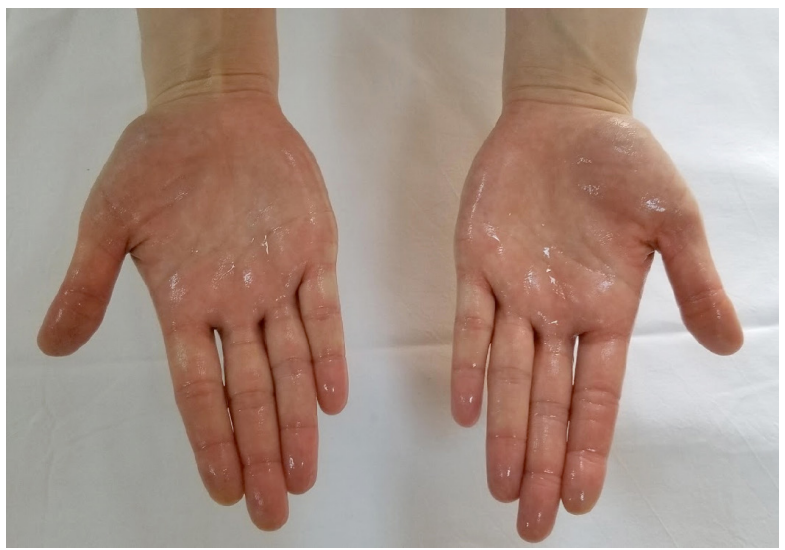

Figure 1. A patient with palmar hyperhidrosis.

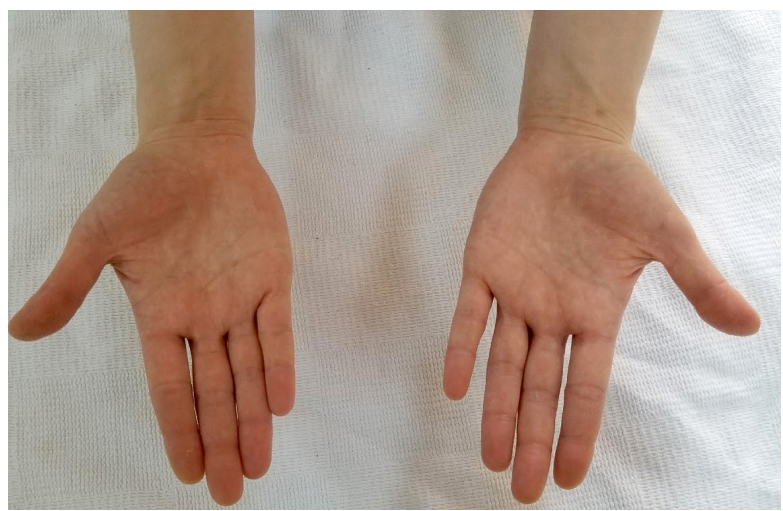

Figure 2. Lack of palmar sweating following endoscopic thoracic sympathectomy procedure. 
ventilation shortly during entry into the thorax to prevent parenchymal injury. In cases of palmar hyperhidrosis, the T2-T3 sympathetic ganglia were destroyed, and in cases of axillary hyperhidrosis, the T2-T4 sympathetic ganglia and accompanying Kuntz nerve were cauterized using endoscopic instruments. After hemostatic control was achieved, a suction catheter was used to aspirate the air in the thorax cavity. When a cardiac status assessment on the monitor indicated that the patient did not have bradycardia, the same procedure was performed on the left side. All of the patients were taken to the clinic after a control chest X-ray was obtained.

The operating time, postoperative expansion, pain, and complications were monitored and recorded. Operative time was recorded as the time between the first skin incision and skin closure after the bilateral sympathectomy.

\section{RESULTS}

The mean operative time ( $33 \pm 3$ minutes) was calculated using the time elapsed for the connection on either side of the thoracoscopic device. Pneumothorax did not develop in any patient. After the procedure, paracetamol was administered at a dose of $\mathrm{I} g$ intravenous at 8 hour intervals as standard analgesia. In a survey performed, the mean severity of back pain reported by all of the patients was 4 points (range: $3-6$ points) according to a visual pain scale. There was no pain at the port site. All of the patients were discharged on the postoperative first day. Patients complained of the development of mild compensatory hyperhidrosis on their feet $(n=2)$, and other body regions $(n=3)$, but the patients were not dissatisfied with the operation.

\section{DISCUSSION}

We are encountering patients in our daily practice who are complaining of regional extreme sweating and seeking medical help at an increasing rate as a result of the developments in social life and increased awareness of the treatment options. Patients typically seek help from various branches of medicine before they resort to surgical alternatives, and it is important that secondary etiologies, such as endocrine causes, tumors, and neurological pathologies are ruled out. It is also recommended that the psychological background of patients who are scheduled for surgery is examined, and that the procedure is fully explained and informed consent is provided.

The classic thoracotomy has been largely abandoned due to development of pain and other complications, and a considerably long incision scar for a procedure that can be considered an esthetic intervention. The first thoracic sympathectomy was performed by Kotzareff in 1920 and surgery for sympathetic ganglia of T2, T3, and T4 was performed by Leriche in 1937..$^{[4,5]}$ It has been reported in further studies that removal of the T2 ganglion alone is sufficient in the treatment of palmar hyperhidrosis. ${ }^{[5]}$ Endoscopic application and identification of this procedure was performed by Kux for the first time in 195I. ${ }^{[6]}$

Nowadays, generally, the procedure is applied bilaterally in the same session. Although it has been reported in the literature that cardiac problems may develop after simultaneous bilateral interventions, no side effects were observed in any of our patients. ${ }^{[7,8]}$ Although it has been recommended that if bradycardia develops after the sympatholysis is performed on the right side that the left side should not be intervened upon, our cases were observed on a monitor and since bradycardia did not develop, the procedure was performed bilaterally.

In the literature, intraoperative and postoperative complications that have been reported include bleeding, subcutaneous emphysema, pulmonary parenchymal injury, prolonged air leak, and brachial plexus injury. ${ }^{[9]}$ In a multicenter study, complications reported were transient Horner syndrome, pneumothorax, and prolonged pain syndrome. ${ }^{[10]}$ In our cases, no instances of Horner syndrome or prolonged pain complaints were seen, and we concluded that pneumothorax did not develop because no single-lung ventilation is performed with a laryngeal mask application.

Endoscopic bilateral thoracic sympathectomy has been reported as a procedure performed in 2 separate sessions, with double lumen intubation, and 2 port incisions, and in some centers, with thoracic drainage. ${ }^{[1]}$ Both a laryngeal mask application and a single port incision have been safely applied in our clinic, which shortens the operation time, and eliminates additional time and effort for double lumen intubation. Furthermore, it prevents complications due to intubation and eliminates the risk of postoperative expansion defect.

Ethics Committee Approval

The study protocol was approved by the local Ethics Committee.

\section{Informed Consent}

A written informed consent was obtained from each patient.

\section{Peer-review}

Internally peer-reviewed.

Authorship Contributions

Concept: E.E.C., K.B.O., F.D.G.; Design: E.E.C., K.B.O., F.D.G.; Analysis and/or interpretation: A.Ö., F.T.O.; Literature search: E.E.C.; Writing: E.E.C.; Critical review: R.D.

Conflict of Interest

None declared. 


\section{REFERENCES}

1. Vetrugno R, Liguori R, Cortelli P, Montagna P. Sympathetic skin response: basical mechanisms and clinical applications. Clin Auton Res 2003;13:256-70. [CrossRef]

2. Romero FR, Miot HA, Haddad GR, Cataneo DC. Palmar hyperhidrosis: clinical, pathophysiological, diagnostic and therapeutic aspects. An Bras Dermatol 2016;91:716-25. [CrossRef]

3. Onder M, Aksoy G. Hyperhidrosis. Turkderm-Turk Arch Dermatol Venereology 2011;45:2-9.

4. Kotzareff A. Résection partielle du tronc sympathique cervical droit pour hyperhidrose unilatérale (regions faciale, cervicale, thoracique et brachiale droites). Rev Med Suisse Romande 1920;40:111-3.

5. Lee DY, Yoon YH, Skin HK, Kim HK, Hong YJ. Needle thoracic sympathectomy for essential hyperhidrosis: intermediate-term follow-up. Ann Thorac Surg 2000;69:251-3. [CrossRef]

6. Yim AP, Liu HP, Lee TW, Wan S, Arifi AA. 'Needlescopic' video-as- sisted thoracic surgery for palmar hyperhidrosis. Eur J Cardiothorac Surg 2000;17:697-701. [CrossRef]

7. Vigil L, Calaf N, Codina E, Fibla JJ, Gómez G, Casan P. Video-assisted sympathectomy for essential hyperhidrosis: effects on cardiopulmonary function. Chest 2005;128:2702-5. [CrossRef]

8. Gossot D, Kabiri H, Caliandro R, Debrosse D, Girard P, Grunenwald D. Early complications of thoracic endoscopic sympathectomy: a prospective study of 940 procedures. Ann Thorac Surg 2001;71:1116-9. [CrossRef]

9. Işıtmangil T, Görür R, Tunç H, Sebit S, Erdik O, Çermik H, et al. Results of thoracoscopic thoracic sympathectomy with two-thoracoports running title: two-ports thoracic sympathectomy. Koşuyolu Heart Journal 2002;6:31-6.

10. Martin A, Telford R. Anaesthesia for endoscopic thoracic sympathectomy. Contin Educ Anaesth Crit Care Pain 2009;9:52-5. [CrossRef]

11. Dewey TM, Herbert MA, Hill SL, Prince SL, Mack MJ. One-year follow-up after thoracoscopic sympathectomy for hyperhidrosis: outcomes and consequences. Ann Thorac Surg 2006;81:1227-32.

\section{Non-entübe İki Taraflı Uniportal Endoskopik Torakal Sempatektomi}

Amaç: Bölgesel aşııı terleme, kişinin hayatını psikolojik ve fiziksel olarak etkileyen, kısıtlayan bir durum olup, düzeltilmesi için cerrahi yönteme başvurular gün geçtikçe artmaktadır. Sıklıkla yüz, eller, ayak tabanları ve veya aksiller bölgede terleme mevcuttur. Çalışmamızda nonentübe olarak gerçekleştirdiğimiz olgularımızın sonuçlarını paylaşmayı amaçladık.

Gereç ve Yöntem: Bu çalışmaya, Ocak 2016-Ocak 2017 tarihleri arasında kliniğimizde gerçekleştirmiş olduğumuz 35 non-entübe bilateral endoskopik torakal sempatektomi olgusu dahil edildi. Hastalara cerrahi işlem öncesi laringeal maske uygulandı.

Bulgular: Hastaların operasyon süreleri, ameliyat sonrası ekspansiyon, ağıı ve komplikasyon durumları takibe alınarak kaydedildi. Ortalama $2 I \pm 3$ dakika olan süreye torakoskopi cihazının iki tarafta da bağlantı süresi dahil edilerek hesaplandı. Hiçbir hastada pnömotoraks gelişmedi. İşlem sonrası standart analjezi uygulanan hastalarda ağrı şikayeti olmadı. Tüm hastalar takip sonrası ameliyat sonrası birinci gün taburcu edildi. Takiplerinde iki hastada ayaklarda hafif kompansatuvar hiperhidrozis şikayeti gelişti fakat hastalarda operasyona ait memnuniyetsizlik oluşturmadı.

Sonuç: Endoskopik bilateral torakal sempatektomi işlemi çeşitli merkezlerde ayrı seanslarda, çift lümenli entübasyon ile, iki port kesisi ile ve bazı merkezlerde toraks dreni ile sonlandırılan bir prosedür olarak bildirilmektedir. Gerek laringeal maske uygulaması, gerek tek port insizyonu, operasyon süresini kısaltan, çift lümenli entübasyon için işlem gereken ek süre ve eforun olmadığı, beraberinde entübasyona bağlı komplikasyonları engelleyen, işlem sonrası pnömotoraks riskini neredeyse ortadan kaldıran bir yöntem olarak kliniğimizde güvenle uygulanmaktadır.

Anahtar Sözcükler: Endoskopik torakal sempatektomi; non-entube VATS; primer hiperhidrozis; uniportal VATS. 